\title{
Plant regeneration via indirect somatic embryogenesis and optimisation of genetic transformation in Coffea arabica L. cvs. Caturra and Catuaí
}

\author{
Andrés M. Gatica-Arias* ${ }^{\#}$ \\ Centro de Investigación en Biología Celular y Molecular \\ Universidad de Costa Rica \\ P.O. Box 2060, San Pedro, Costa Rica \\ Tel: 5062075091 \\ Fax: 5062074216 \\ E-mail: agatica@biologia.ucr.ac.cr \\ Griselda Arrieta-Espinoza \\ Centro de Investigación en Biología Celular y Molecular \\ Universidad de Costa Rica \\ P.O. Box 2060, San Pedro, Costa Rica \\ Tel: 5062073198 \\ Fax: 5062073190 \\ E-mail: griselda.arrieta@gmail.com \\ Ana M. Espinoza Esquivel \\ Centro de Investigación en Biología Celular y Molecular \\ Universidad de Costa Rica \\ P.O. Box 2060, San Pedro, Costa Rica \\ Tel: 5062073198 \\ Fax: 5062073190 \\ E-mail: amespino@gmail.com
}

Financial support: This research was supported by the Costa Rica - United States of America Foundation for Cooperation (CRUSA) and the University of Costa Rica.

Keywords: bioreactor, coffee, genetic transformation, somatic embryogenesis, suspension cultures.

Present address: "Escuela de Biología, Sede Universitaria Rodrigo Facio, Universidad de Costa Rica. P.O. Box 2060, San Pedro, Costa Rica. Tel: 506207 50 91; Fax: 5062074216
Abbreviations: 2,4-D: 2,4-dichlorophenoxyacetic acid
BAP: benzylaminopurine
ISE: indirect somatic embryogenesis
RITA $^{\circledR}$ : Recipient for Automated Temporary Immersion System
TDZ: thidiazuron

A protocol for Coffea arabica L. cvs. Caturra and Catuaí plant regeneration via indirect somatic embryogenesis (ISE) was established. Furthermore, a biolistic mediated genetic transformation protocol was optimized for Catuaí callus aggregates. Maximum callus induction was obtained when Caturra (87\%) and Catuaí (67\%) leaves were cultured on Murashige and Skoog medium with $18.56 \mu \mathrm{M}$ kinetin and 4.52 $\mu \mathrm{M} 2,4-$ dichlorophenoxyacetic acid (2,4-D). Catuaí suspension cultures were established from embryogenic callus using liquid proliferation CP and Sli media and diffused light and darkness. The higher suspension cultures fresh weight was obtained using Erlenmeyer (1425.4 \pm 354.9 mg) than Recipient for Automated Temporary Immersion System $\left(\right.$ RITA $\left.^{\circledR}\right)(518.6 \pm 55.1 \mathrm{mg})$, whereas the dry weight of suspension cultures was not significantly affected by the culture system used. Higher number of embryos per vessel $(307.6 \pm 49.0)$ and their fresh weight $(9.6 \pm 1.5 \mathrm{mg})$ were obtained with semisolid $R$ medium than S3 medium. The highest somatic embryo development $(25.0 \pm 2.7)$ and fresh weight $(780.0 \pm 85.4 \mathrm{mg})$ were obtained with $1 \mathrm{~min}$ of immersion every 8 hrs. Higher fresh weight of regenerated plantlets was obtained with liquid Yasuda medium in RITA ${ }^{\circledR}(124.6 \pm 16.3 \mathrm{mg})$ than semisolid media ( $36.3 \pm 11.3 \mathrm{mg})$. For genetic transformation, the effect of helium pressure (900 and $1550 \mathrm{psi}$ ), and target distance $(9$ and $12 \mathrm{~cm}$ ) and plasmid (PCAMBIA 1301, PCAMBIA 1305.2 and pCAMBIA 1301-BAR) on transient uidA expression Catuaí suspension cultures

*Corresponding author 
were evaluated. The highest number of blue spots was obtained using 900 psi and $9 \mathrm{~cm}(125.8 \pm 17.3)$. Stable uidA expression was observed on Catuaí callus aggregates transformed with PCAMBIA 2301 and cultured on $100 \mathrm{mg} \mathrm{l}^{-1}$ of kanamycin.

Coffee (Coffea arabica L.) is one of the most economic important crops for more than 50 countries in the world and it is highly valuable for beverage consumption. Nevertheless, among several factors, coffee production is affected by seed and cuttings low multiplication rates and susceptibility to different diseases and pests. Techniques such as plant tissue culture and plant transformation can contribute to coffee improvement and accelerate the release of varieties with new traits (Santos-Briones and HernándezSotomayor, 2006).

Micropropagation constitutes an alternative for the mass propagation of selected coffee clones and hybrids (Etienne et al. 2002). Moreover, genetic transformation of coffee varieties requires development of efficient in vitro culture systems to obtain competent explants for plant transformation and regeneration (Fernández-Da Silva and Menéndez-Yuffá, 2003). Somatic embryogenesis has been preferred over other in vitro developmental processes, such as organogenesis or axillary bud proliferation, for micropropagation and genetic modification of higher plants (Ogita et al. 2002). In coffee, this process has been achieved via direct somatic embryogenesis from proembryogenic cells of the leaf tissue in the absence of conspicuous callus proliferation or by indirect somatic embryogenesis (ISE) via friable embryogenic callus formation (Molina et al. 2002). Embryogenic callus cultures are obtained after culture of explants on an auxin containing medium. Thereafter, subculture on auxin free medium induces embryo regeneration (van Boxtel and Berthouly, 1996).

ISE in coffee comprises a sequence of steps including callus induction and proliferation, and embryo development, as well as germination and conversion into plants (van Boxtel and Berthouly, 1996). The use of liquid medium has enabled the proliferation and mass production of somatic embryos in Erlenmeyer flasks or bioreactors in C. arabica and C. canephora (Zamarripa et al. 1991; van Boxtel and Berthouly, 1996; Barry-Etienne et al. 1999; Barry-Etienne et al. 2002a; Quiroz-Figueroa et al. 2002; Santana et al. 2004). Previous investigations have been conducted to compare the efficiency of liquid systems using Erlenmeyer flasks and bioreactors (Berthouly et al. 1995), the composition of culture media (Neuenschwander and Baumann, 1992; van Boxtel and Berthouly, 1996; QuirozFigueroa et al. 2001), the culture density (van Boxtel and Berthouly, 1996; Santana et al. 2004), the callus age (Santana et al. 2004), and the subculture intervals (van Boxtel and Berthouly, 1996). In those cases in which bioreactors have been used, the duration and the frequency of immersion have been also studied (Albarrán et al. 2005).
Genetic transformation of C. arabica and C. canephora has been reported using Agrobacterium tumefaciens (Hatanaka et al. 1999; Leroy et al. 2000; Ogita et al. 2002; CancheMoo et al. 2006), Agrobacterium rhizogenes (Alpizar et al. 2006; Kumar et al. 2006) electroporation (Fernandez-Da Silva and Menéndez-Yuffá, 2003) and biolistic (van Boxtel et al. 1995; Rosillo et al. 2003; Ribas et al. 2005). These investigations have been conducted in order to optimize the transformation parameters using marker genes, to confer resistance to insects and herbicides or to reduce the caffeine content (Santos-Briones and Hernández-Sotomayor, 2006).

Several protocols have been described in the literature for plant regeneration of coffee via ISE; nevertheless, specific conditions and protocols developed for a particular genotype are not necessarily reproducible for others (van Boxtel and Berthouly, 1996; Molina et al. 2002; Santana et al. 2004). Moreover, it has been shown that somaclonal variation among coffee plants regenerated through somatic embryogenesis range from $2 \%$ to $10 \%$ and it depends on the genotype, explant source, culture age, type and concentration of plant growth regulators, ploidy levels and chromosome number (Etienne and Bertrand, 2001; Etienne and Bertrand, 2003). However, ISE would facilitate large scale production of embryogenic calli and of somatic embryos for genetic transformation experiments and mass propagation of selected coffee clones and hybrids (van Boxtel and Berthouly, 1996; Etienne et al. 2002).

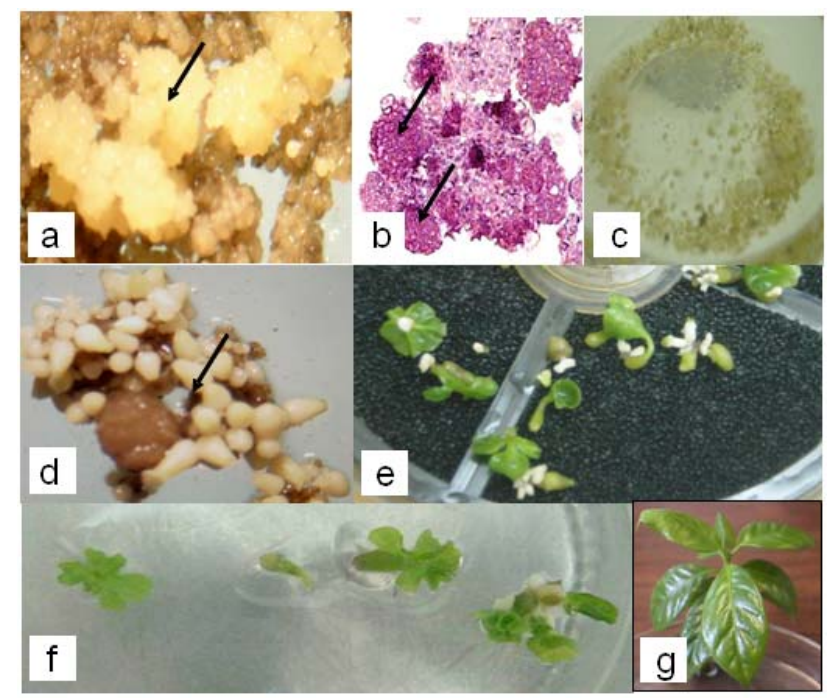

Figure 1. ISE from Coffea arabica L. cv. Caturra and Catuaí leaves. (a) embryogenic callus (arrow). (b) Clusters of embryogenic cells (arrows) of Catuaí suspension cultures observed by light microscopy (40X). (c) Proliferation of Catuaí embryogenic calli in liquid Sli medium (d) Somatic embryo formation from Catuaí suspension culture (arrow). (e) Germination and somatic embryos conversion into plantlets in RITA $^{\circledR}$ with $R$ liquid media. (f) Germination and somatic embryos conversion into plantlets in RITA ${ }^{\circledast}$ with $\mathrm{R}$ semisolid media. (g) Coffee plants regenerated using RITA $^{\circledast}$ and semisolid culture media. 
Table 1. Effect of BAP, TDZ and Kinetin on embryogenic callus induction in coffee (Coffea arabica L. cv. Caturra and Catuaí) 16 weeks of culture on S1 + S2 media.

\begin{tabular}{|c|c|c|c|c|c|}
\hline \multicolumn{3}{|c|}{ Growth regulators $(\mu \mathrm{M})$} & \multicolumn{2}{c|}{ Callus formation (\%) } \\
\hline $2,4-D$ & BAP & TDZ & KIN & Caturra & Catuaí \\
\hline 4.52 & - & - & 18.5 & $87 \mathrm{a}$ & $67 \mathrm{a}$ \\
\hline 4.52 & 4.4 & - & - & $19 \mathrm{~b} \mathrm{c}$ & $8 \mathrm{~b}$ \\
\hline 4.52 & 8.9 & - & - & $11 \mathrm{~b} \mathrm{c}$ & $9 \mathrm{~b}$ \\
\hline 4.52 & 13.2 & - & - & $6 \mathrm{~b} \mathrm{c}$ & $11 \mathrm{~b}$ \\
\hline 4.52 & 17.6 & - & - & $6 \mathrm{~b} \mathrm{c}$ & $5 \mathrm{~b}$ \\
\hline 4.52 & 22.2 & - & - & $0 \mathrm{~d}$ & $0 \mathrm{c}$ \\
\hline 4.52 & - & 2.2 & - & $9 \mathrm{~b} \mathrm{c}$ & $3 \mathrm{~b}$ \\
\hline 4.52 & - & 4.5 & - & $15 \mathrm{~b} \mathrm{c}$ & $3 \mathrm{~b}$ \\
\hline 4.52 & - & 6.8 & & $0 \mathrm{~d}$ & $0 \mathrm{c}$ \\
\hline
\end{tabular}

Same letters within columns denote statistically equal means with the Duncan test at $P<0.05$.

Therefore, the aim of this research was to define the best conditions for embryogenic callus induction and proliferation, as well as for embryo development and germination of somatic embryos from suspension cultures of coffee (Coffea arabica L. cv. Caturra and Catuaí) by studying the influence of culture media composition, light condition, culture system (semisolid vs. bioreactor) and immersion duration in bioreactor. Moreover, using the system for plant regeneration via ISE of Coffea arabica L. established in this study, our purpose was to optimize the biolistic parameters that affect the DNA delivery and stable expression of marker genes into Catuaí suspension cultures.

\section{MATERIALS AND METHODS}

\section{Plant material}

Seeds of Caturra and Catuaí, collected from coffee plantations in Alajuela, Costa Rica, were washed and soaked for $24 \mathrm{hrs}$ in distilled water with two drops of Tween 20, disinfected with $3.5 \%$ (v/v) sodium hypochlorite for $1 \mathrm{hr}$ and finally rinsed three times with sterile distilled water. The zygotic embryos were excised from the seeds and cultured in baby food jars closed with polyethylene food wrap (Glad, Costa Rica) containing $20 \mathrm{ml}$ of MS medium (Murashige and Skoog, 1962) supplemented with Morel vitamins (Morel, 1965), $100 \mathrm{mg} \mathrm{l}^{-1}$ myo-inositol, 200 $\mathrm{mg} \mathrm{l}^{-1}$ casein hydrolysate, $400 \mathrm{mg} \mathrm{l}^{-1}$ malt extract, $4.4 \mu \mathrm{M}$ 6-benzylaminopurine (BAP) and $2 \mathrm{~g} \mathrm{l}^{-1}$ Gelrite; $\mathrm{pH}$ was adjusted to 5.6 before autoclaving for $21 \mathrm{~min}$ at $121^{\circ} \mathrm{C}$ and $1.07 \mathrm{~kg} \mathrm{~cm}^{-2}$. In vitro plantlets developed from these embryos were cultured with $20 \mathrm{ml}$ of the above medium under a 16 hrs light photoperiod $\left(30 \mu \mathrm{mol} \mathrm{m}^{-2} \mathrm{~s}^{-1}\right)$ at $26 \pm$ $2^{\circ} \mathrm{C}$ and transferred to fresh medium every 90 days.

\section{Induction of embryogenic callus and establishment of suspension cultures}

First and second completely developed leaves from the in vitro plants were used as explants for callus induction. Leaf sections measuring $0.5 \mathrm{~cm}^{2}$, without the midvein and the margins, were placed with the abaxial surface upwards on $10 \mathrm{ml}$ of callus induction medium contained in culture tubes $(21 \times 150 \mathrm{~mm})$. For the first culture step, the medium C (van Boxtel and Berthouly, 1996) supplemented with 9.8 $\mu \mathrm{M}$ 2-isopenteniladenine (2-iP), $2.2 \mu \mathrm{M} \quad$ 2,4dichlorophenoxyacetic acid (2,4-D) and 4.9 $\mu \mathrm{M}$ indole-3butyric acid(IBA) and the medium S1 (Sondahl et al. 1991) complemented with $18.5 \mu \mathrm{M}$ kinetin and $4.5 \mu \mathrm{M}$ 2,4-D were tested. After one month of culture on $\mathrm{C}$ and $\mathrm{S} 1$ medium, the primary callus and explants were subcultured in culture tubes containing $10 \mathrm{ml}$ of the embryo induction medium E (van Boxtel and Berthouly, 1996) and S2 (Sondahl et al. 1991) respectively.

The cytokinins of the original callus induction media $\mathrm{C}$ and S1 were replaced by several concentrations of BAP (4.4, 8.9, 13.2, 17.6 and $22.2 \mu \mathrm{M}$ ) or thidiazuron (TDZ) (2.2, 4.5 and $6.8 \mu \mathrm{M}$ ) in order to evaluate their effect on callus formation. The explants were cultured in the dark at $26 \pm$ $2^{\circ} \mathrm{C}$. Percentage of callus formation [(explants with embryogenic callus/total of explants)* 100] was evaluated after 16 weeks of culture on S1 + S2 or C + E.

To start embryogenic suspension cultures, $250 \mathrm{mg}$ fresh weight of friable embryogenic callus were transferred into $25 \mathrm{ml}$ of liquid proliferation medium CP (van Boxtel and Berthouly, 1996) contained in $125 \mathrm{ml}$ Erlenmeyer flasks. To determine cell viability, one $\mathrm{ml}$ of suspension cultures was placed in a microcentrifuge tubes and centrifugated at $1000 \mathrm{rpm}$ and $100 \mu \mathrm{l}$ of Evans Blue (0.1\% w/v) was added $10 \mathrm{~min}$ at room temperature, centrifuged at $1000 \mathrm{rpm}$ and

Table 2. Proliferation of suspension cultures of coffee (Coffea arabica L. cv. Catuaí) using RITA ${ }^{\circledR}$ and Erlenmeyer flasks after 4 weeks of culture on Sli medium in the dark.

\begin{tabular}{|c|c|c|}
\hline Culture system & $\begin{array}{c}\text { Fresh } \\
\text { weight (mg) }\end{array}$ & $\begin{array}{c}\text { Dry } \\
\text { weight (mg) }\end{array}$ \\
\hline RITA $^{\circledR}$ & $518.6 \pm 55.1 \mathrm{~b}$ & $89.2 \pm 4.6 \mathrm{a}$ \\
\hline Erlenmeyer & $1425.4 \pm 354.9 \mathrm{a}$ & $109.6 \pm 18.2 \mathrm{a}$ \\
\hline
\end{tabular}

Each value represents the mean \pm SE of 5 replicates from different RITA ${ }^{\circledR}$ and Erlenmeyer flasks. Same letter within columns denotes denote statistically equal means with the Duncan test at $P<0.05$. 


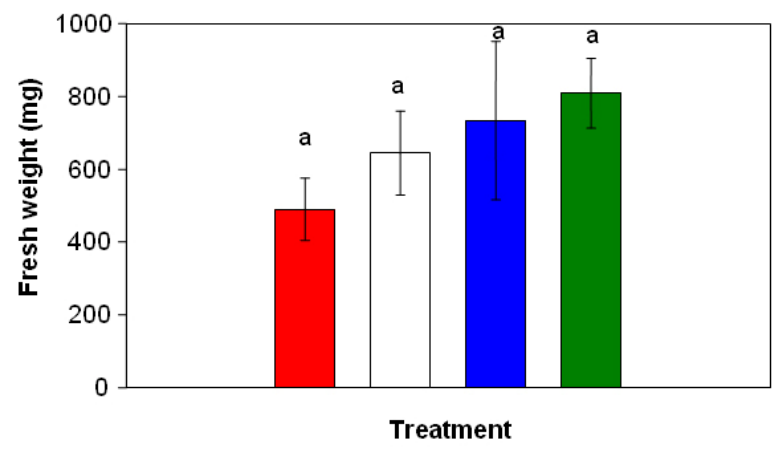

$\square$ CP Diffused light $\square$ CP Darkness $\square$ Sli Diffused light $\square$ Sli Darkness

Figure 2. Influence of culture medium and light condition on fresh weight of suspension cultures of coffee (Coffea arabica L. cv. Catuaí). Evaluation was conducted after 4 weeks of culture on CP and Sli medium under diffused light with $12 \mathrm{hrs}$ light photoperiod or in the dark. Each value represents the mean \pm SE of 5 replicates from different Erlenmeyer flasks. Same letter above columns denotes denote statistically equal means with the Duncan test at $P<0.05$.

resuspended in distilled water. Viability was determined by counting the coloured cells in a hemacytometer using an Olympus BX41 microscope.

Histological analysis of the suspension cultures was performed by fixing the tissue for 24 hrs in a solution containing $10 \%(\mathrm{v} / \mathrm{v})$ formalin in $0.2 \mathrm{M}$ phosphate buffer. Then, the suspension cultures were dehydrated in a graded series of ethanol and embedded in paraffin wax. Six $\mu \mathrm{m}$ sections were stained with Haematoxylin-Eosin and photographs were taken using an Olympus BX41 microscope.

\section{Proliferation of suspension cultures}

Six-month-old suspension cultures of C. arabica cv Catuaí were used for the following experiments. Two culture media and light conditions were evaluated for the proliferation of Catuaí suspension cultures. Two hundred and fifty milligrams fresh weight of suspension cultures were cultured in $25 \mathrm{ml}$ of liquid proliferation CP (van Boxtel and Berthouly, 1996) or Sli medium (QuirozFigueroa et al. 2002) in $125 \mathrm{ml}$ Erlenmeyer flasks under diffused light with 12 hrs light photoperiod $\left(30 \mu \mathrm{mol} \mathrm{m}{ }^{-2}\right.$ $\mathrm{s}^{-1}$ ) or in the dark. The suspension cultures were maintained on a gyratory shaker at $100 \mathrm{rpm}$ at $26 \pm 2^{\circ} \mathrm{C}$. In a second experiment, $250 \mathrm{mg}$ fresh weight of suspension cultures were cultured either in $25 \mathrm{ml}$ of liquid medium in $125 \mathrm{ml}$ Erlenmeyer flasks or in the Recipient for Automated Temporary Immersion System (RITA ${ }^{\circledR}$ ) with $200 \mathrm{ml}$ of liquid media and with a 1 min immersion period every 8 hrs. In every experiment, five Erlenmeyer flasks and five RITA $^{\circledR}$ containers were used simultaneously. Proliferation of suspension cultures was measured by determining the fresh weight and dry weight after 4 weeks of culture.

\section{Development of somatic embryos from suspension cultures}

Catuaí somatic embryo development was evaluated using two culture systems: plating them on $20 \mathrm{ml}$ semisolid medium (gelled with $2.5 \mathrm{~g} \mathrm{l}^{-1}$ Gelrite) contained in Petri dishes (100 mm x $20 \mathrm{~mm}$ ) or culturing in RITA ${ }^{\circledR}$ containers with $200 \mathrm{ml}$ liquid medium. In both conditions, R (van Boxtel and Berthouly, 1996) and S3 (Quiroz-Figueroa et al. 2002) culture media were tested. Two hundred and fifty milligrams fresh weight of suspension cultures were

Table 3. One-way Anova for the variables analysed.

\begin{tabular}{|l|c|c|c|c|c|}
\hline \multicolumn{1}{|c|}{ Number of somatic embryos } & Sum of square & gl & Mean square & F & p \\
\hline Effect of culture media composition & 436896.80 & 1 & 436896.80 & 48.69 & 0.0001 \\
\hline Effect of culture system & 27084.80 & 1 & 27084.80 & 3.02 & 0.1015 \\
\hline Fresh weight of somatic embryos & & & & \\
\hline Effect of culture media composition & 425.04 & 1 & 425.04 & 48.51 & 0.0001 \\
\hline Effect of culture system & 26.45 & 1 & 26.45 & 3.02 & 0.1015 \\
\hline Fresh weight of embryogenic callus & & & & & \\
\hline Effect of culture media composition & 26.61 & 1 & 26.61 & 44.59 & 0.0001 \\
\hline Effect of culture system & 0.19 & 1 & 0.19 & 0.31 & 0.5841 \\
\hline
\end{tabular}


Table 4. Effect of culture medium on somatic embryo formation from suspension cultures of Coffea arabica L. cv. Catuaí after 8 weeks of culture using Petri dishes and RITA containers.

\begin{tabular}{|c|c|c|c|}
\hline & & \multicolumn{2}{|c|}{ Fresh weight } \\
$\begin{array}{c}\text { Culture } \\
\text { medium }\end{array}$ & $\begin{array}{c}\text { Number of } \\
\text { somatic } \\
\text { embryos }\end{array}$ & $\begin{array}{c}\text { Somatic } \\
\text { embryos } \\
\text { (mg) }\end{array}$ & $\begin{array}{c}\text { Embryogenic } \\
\text { callus } \\
\text { (g) }\end{array}$ \\
\hline R & $307.6 \pm 49.0 \mathrm{a}$ & $9.6 \pm 1.5 \mathrm{a}$ & $1.15 \pm 0.2 \mathrm{~b}$ \\
\hline S3 & $12.0 \pm 5.2 \mathrm{~b}$ & $0.4 \pm 0.2 \mathrm{~b}$ & $3.50 .4 \mathrm{a}$ \\
\hline
\end{tabular}

Same letters within columns denote statistically equal means with the Duncan test at $P<0.05$.

cultured per Petri dish or RITA ${ }^{\circledR}$ container. The immersion period for the latter was 1 min every $8 \mathrm{hrs}$. Once the best combination of culture medium and culture system was determined, a second experiment was carried out, to evaluate the effect of the immersion period on somatic embryo development as follows: $1 \mathrm{~min}, 5 \mathrm{~min}$ and $10 \mathrm{~min}$ every 8 hrs. In both experiments, five RITA ${ }^{\circledR}$ containers and five Petri dishes were used. The suspension cultures were kept under $16 \mathrm{hrs}$ light photoperiod $\left(30 \mu \mathrm{mol} \mathrm{m}^{-2} \mathrm{~s}^{-1}\right)$ at $26 \pm 2{ }^{\circ} \mathrm{C}$. For both experiments, the total number of somatic embryos, fresh weight of somatic embryos and fresh weight of tissue were determined after 8 weeks of culture.

\section{Germination of somatic embryos and conversion into plantlets}

Torpedo somatic embryos of Catuaí were germinated on 20 $\mathrm{ml}$ semisolid or $200 \mathrm{ml}$ liquid Yasuda medium (Yasuda et al. 1985) contained in baby food jars or RITA ${ }^{\circledR}$, respectively. Semisolid medium was gelled with $2.5 \mathrm{~g} \mathrm{l}^{-1}$ Gelrite. Ten somatic embryos were cultured in each baby food jar and 20 somatic embryos in each RITA ${ }^{\circledR}$ container with an immersion time of 1 min every 8 hrs. Once the best germination medium was determined, a second experiment was carried out, to evaluate the effect of the immersion period on somatic embryo germination as follows: $1 \mathrm{~min}, 5$ min and 10 min every 8 hrs. Five baby food jars and five RITA $^{\circledR}$ containers were used simultaneously in each experiment. The explants were cultured under $16 \mathrm{hrs} \mathrm{light}$ photoperiod $\left(30 \mu \mathrm{mol} \mathrm{m} \mathrm{s}^{-2}\right)$ at $26 \pm 2^{\circ} \mathrm{C}$. The total number of germinated somatic embryos, fresh weight of somatic embryos and embryogenic callus and conversion of somatic embryos into plantlets were assessed after 12 weeks of culture in the conditions described above. The percentage of germination [(germinated somatic embryos/total of somatic embryos) $\mathrm{x}$ 100] and the conversion of embryos into plants [(Number of plants with two pairs of true leaves/total of somatic embryos) x 100] were calculated.

\section{Preparation of plasmid DNA}

The plasmid pCAMBIA 1301 (Center for the Application of Molecular Biology to International Agriculture, Canberra, Australia), containing a uidA gene and the $h p t$ gene, both under control of the constitutive CaMV35S promoter, was used for biolistic optimisation. The plasmid was isolated from Escherichia coli XL1 cells using the Wizard $^{\mathrm{TM}}$ Plus Midipreps DNA purification systems (Promega). Ten $\mu$ l of DNA $\left(1 \mu \mathrm{g} \mathrm{l}^{-1}\right)$ were precipitated onto $50 \mu \mathrm{l}$ sterile gold particles $(1 \mu \mathrm{M}$, Bio-Rad Laboratories Inc, Hercules, CA, USA) following the protocol described by Russell (1993).

\section{Optimization of DNA delivery into suspension cultures}

Prior to particle bombardment, $250 \mathrm{mg}$ of Catuaí suspension cultures were cultured on a Petri dish for $4 \mathrm{hrs}$ on filter paper placed on top of Yasuda et al. (1985) medium supplemented with $0.5 \mathrm{M}$ mannitol and $0.5 \mathrm{M}$ sorbitol (Rosillo et al. 2003). Suspension cultures were bombarded with the plasmid pCAMBIA 1301 using either 900 psi with a target distance of $9 \mathrm{~cm}$ or 1550 psi with 12 $\mathrm{cm}$ according to Rosillo et al. (2003). In all the experiments, 10 Petri dishes were bombarded once and cultured in the dark at $26 \pm 2^{\circ} \mathrm{C}$. Additionally, nonbombarded suspension cultures were included as controls.

Once the best helium pressure and target distance were determined, smaller suspension cultures $(0.1-0.3 \mathrm{~cm})$ and small calli aggregates $(0.5-1.0 \mathrm{~cm})$ were bombarded with

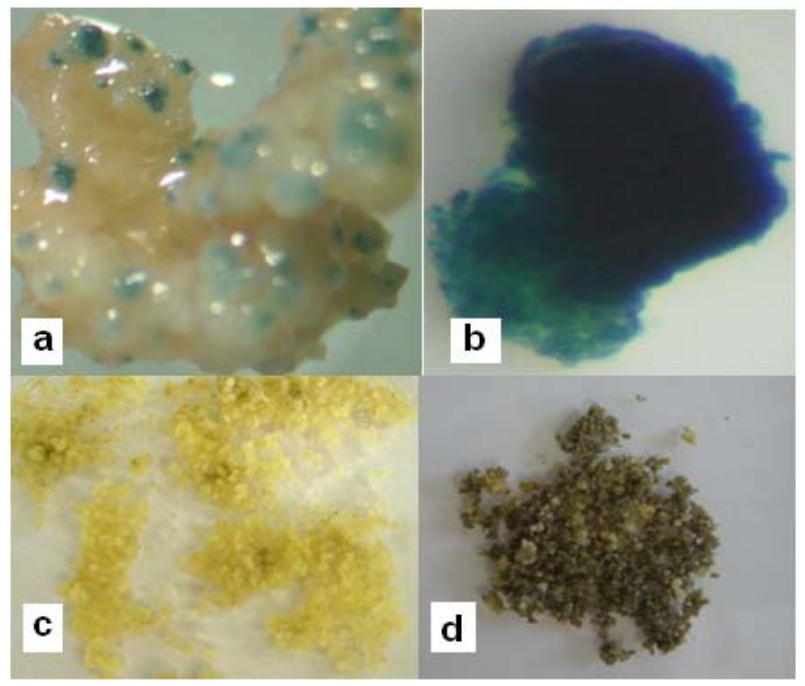

Figure 3. Histochemical assay of uidA gene. (a) Transient uidA expression on Catuaí suspension cultures bombarded with pCAMBIA 1301. (b) Stable uidA expression on Catuaí suspension cultures bombarded with pCAMBIA 2301 after 4 weeks of culture on Sli medium (Quiroz-Figueroa et al. 2002) supplemented with $100 \mathrm{mg} \mathrm{l}^{-1}$ kanamycin. (c) Catuaí suspension cultures on selection with $100 \mathrm{mg} \mathrm{l}^{-1}$ kanamycin after 4 weeks of bombardment with PCAMBIA 2301. (d) Complete growth inhibition of Catuaí suspension cultures in selection medium containing $100 \mathrm{mg} \mathrm{l}^{-1}$ hygromycin or $3 \mathrm{mg} \mathrm{l}^{-1}$ ammonium glufosinate. 
the plasmids pCAMBIA 1305.2 (uidA version GUSPlus ${ }^{\mathrm{TM}}$ and the $h p t$ gene), pCAMBIA 1301-BAR (uidA gene and the bar gene) and pCAMBIA 2301 (uidA gene and the nptII gene).

\section{Assay for $\beta$-glucoronidase activity}

Histochemical GUS assays were performed 48 hrs after plasmid delivery following the protocol described by van Boxtel et al. (1995). Briefly, bombarded suspension cultures were incubated in X-Gluc buffer (2 mM X-Gluc, $100 \mathrm{mM}$ sodium phosphate buffer $\mathrm{pH}$ 8.0, $10 \mathrm{mM}$ EDTA, 1 $\mathrm{mM}$ potassium ferricyanide, $1 \mathrm{mM}$ potassium ferrocyanide and $20 \% \mathrm{v} / \mathrm{v}$ methanol) for $24 \mathrm{hrs}$ at $37^{\circ} \mathrm{C}$ in the dark. The tissue was cleared using $95 \%(\mathrm{v} / \mathrm{v})$ ethanol and the transient uidA expression was determined by counting the number of blue spots with a binocular stereoscope.

\section{Selection of putative transformants}

Bombarded Catuaí suspension cultures were cultured on semisolid Sli medium (Quiroz-Figueroa et al. 2002) supplemented with $100 \mathrm{mg} \mathrm{l}^{-1}$ hygromycin (pCAMBIA 1301 and pCAMBIA 1305.2) (Hatanaka et al. 1999), $3 \mathrm{mg}$ $\mathrm{l}^{-1}$ ammonium glufosinate (pCAMBIA 1301-BAR) and 100 $\mathrm{mg} \mathrm{l}^{-1}$ kanamycin (Hatanaka et al. 1999; Canche-Moo et al. 2006) (pCAMBIA 2301). During all selection period, the suspensions cultures were maintained with 16 hrs light photoperiod $\left(30 \mu \mathrm{mol} \mathrm{m} \mathrm{m}^{-2}\right)$ at $26 \pm 2^{\circ} \mathrm{C}$. Four weeks after the selective agent was applied, necrosis of the tissues was evaluated.

\section{Statistical analysis}

Data were analyzed using one-way ANOVA and the differences between treatment means were contrasted using the Duncan test at the level of 5\%. The program STATISTICA version 6.0 (StatSoft, Tulsa, OK, USA) was used.

\section{RESULTS}

Induction of embryogenic callus and
establishment of suspension cultures

A creamy compact primary callus was observed on the cut edges of both Caturra and Catuaí leaf explants after two weeks of culture on callus induction media C and S1. Subsequently, spots of yellow friable embryogenic callus formed on the edges of primary callus after 16 weeks of culture on embryo induction medium E and S2 (Figure 1a). Embryogenic callus was induced only after sequential culture on media S1 and S2. Best results were obtained with $18.5 \mu \mathrm{M}$ kinetin and $4.52 \mu \mathrm{M}$ 2,4-D (Table 1). On the other hand, there was no embryogenic callus formation when Caturra and Catuaí in vitro leaves were cultured on the medium sequence $\mathrm{C}+\mathrm{E}$.

Transfer of embryogenic callus cultures to liquid CP medium induced formation of large number of small aggregates in Catuaí, in contrast globular somatic embryos developed in Caturra. Therefore, it was not possible to establish suspension cultures of the latter genotype. The Evans Blue test shown viability of the Catuaí suspension cultures whereas dead cells shown dark blue colour. The suspension cultures were constituted of small and isodiametric cells with a prominent nucleus and nucleolus and dense cytoplasm (Figure 1b).

\section{Proliferation of suspension cultures}

The fresh weight of suspension cultures was not significantly affected by the proliferation culture media (CP or Sli) or by light conditions (indirect light with $12 \mathrm{hrs} \mathrm{light}$ photoperiod or darkness) tested (Figure 2). On the other hand, independently of the culture media used, illuminated cultures turned brown after 4 weeks. Therefore, darkness was chosen for further experiments (Figure 1c). The present study showed that the higher Catuaí suspension cultures fresh weight was obtained using Erlenmeyer flask than RITA $^{\circledR}$ under the conditions tested. On the other hand, the

Table 5. Effect of duration of immersion period in RITA ${ }^{\circledR}$ containers on formation of somatic embryos from suspension cultures of Coffea arabica L. cv. Catuaí after 8 weeks of culture in R medium.

\begin{tabular}{|c|c|c|c|}
\hline \multirow{2}{*}{ Duration of immersions } & Number of somatic embryos & \multicolumn{2}{|c|}{ Fresh weight } \\
\cline { 2 - 4 } & Somatic embryos (mg) Embryogenic callus (g) \\
\hline 1 min every $8 \mathrm{hrs}$ & $25.0 \pm 2.7 \mathrm{a}$ & $780.0 \pm 85.4 \mathrm{a}$ & $0.7 \pm 0.2 \mathrm{~b}$ \\
\hline 5 min every $8 \mathrm{hrs}$ & $8.0 \pm 2.0 \mathrm{~b}$ & $249.6 \pm 62.4 \mathrm{~b}$ & $1.8 \pm 0.5 \mathrm{ab}$ \\
\hline 10 min every 8 hrs & $8.2 \pm 4.5 \mathrm{~b}$ & $255.8 \pm 142.1 \mathrm{~b}$ & $2.6 \pm 0.2 \mathrm{a}$ \\
\hline
\end{tabular}

Same letters within columns denote statistically equal means with the Duncan test at $P<0.05$. 
dry weight of suspension cultures was not significantly affected by the culture system used (Table 2).

\section{Development of somatic embryos from suspension cultures}

Typical somatic embryos developed from Catuaí suspension cultures are shown in Figure 1d. Their number and fresh weight were significantly affected by the composition of the culture medium used (Table 3). The highest number of somatic embryos per vessel and higher fresh weight were obtained when the suspension cultures were cultured in $\mathrm{R}$ medium in contrast to S3 medium (Table 4). Moreover, the culture medium composition significantly affected the fresh weight of embryogenic callus. Thus, the highest fresh weight of embryogenic callus was obtained using S3 medium (Table 3 and Table 4).

On the other hand, the number of somatic embryos, the fresh weight of somatic embryos and embryogenic callus were not significantly affected by the culture system (semisolid medium vs. liquid medium in RITA ${ }^{\circledR}$ ) (Table 3). Nevertheless, the development of somatic embryos up to the torpedo stage from suspension cultures in semisolid culture media was completed in eight weeks whereas in liquid media in RITA $^{\circledR}$ it was accomplished in six weeks.

The immersion period in the RITA $^{\circledR}$ containers significantly affected the formation of somatic embryos. The highest number of somatic embryos, the highest fresh weight of somatic embryos and the lowest fresh weight of embryogenic calli were obtained using an immersion period of 1 min every $8 \mathrm{hrs}$. Increasing the immersion duration reduced the number and fresh weight of somatic embryos and increased the fresh weight of embryogenic calli (Table $5)$.

\section{Germination of somatic embryos and conversion into plantlets}

Somatic embryos germinated successfully in either semisolid or liquid Yasuda culture medium (Figure 1e and Figure 1f). The germination rate and conversion of somatic embryos into plantlets did not differ statistically between both conditions (Table 6). Nevertheless, using the RITA ${ }^{\circledR}$ system, the conversion of embryos into plantlets took place in four weeks compared to six weeks in semisolid media. Moreover, the highest fresh weigh of plantlets was obtained with the RITA ${ }^{\circledR}$ system (Table 6). In general, the somatic embryos obtained in semisolid Yasuda medium were smaller with underdeveloped cotyledons compared to the somatic embryos regenerated using RITA $^{\circledR}$ which developed larger embryogenic axis with well-defined cotyledons (Figure 1e and Figure 1f). Despite these differences in earlier germination stage, normal subsequent growth and development of the plant was observed. The somatic embryos regenerated into plantlets with two to four pair of leaves and the length of the plant was $5 \mathrm{~cm}$ (Figure $1 \mathrm{~g})$.
The germination rate, conversion of embryos into plantlets and fresh weight of the plants were not significantly affected by immersion period tested (data not shown).

\section{Optimization of DNA delivery into suspension cultures}

Transient uidA expression was observed on Catuaí suspension cultures bombarded using $900 \mathrm{psi}$ and $9 \mathrm{~cm}$ or 1550 psi and $12 \mathrm{~cm}$ (Figure 3a). However, higher number of blue spots per Petri was observed when Catuaí suspension cultures were bombarded with pCAMBIA 1301 using $900 \mathrm{psi}$ and a target distance of $9 \mathrm{~cm}(125.8 \pm 17.3)$ than with $1550 \mathrm{psi}$ and $12 \mathrm{~cm}(30.5 \pm 9.1)$ (Figure 4).

\section{Selection of putative stable transformants}

When smaller Catuaí callus aggregates $(0.1-0.3 \mathrm{~cm})$ were bombarded using 900 psi and $9 \mathrm{~cm}$ with pCAMBIA 1301 or pCAMBIA 1301-BAR, no stable expression of uidA, hpt or bar genes was obtained. In contrast, stable expression of uidA gene was obtained when small Catuaí callus aggregates $(0.5-1 \mathrm{~cm})$ were bombarded with pCAMBIA 2301 (uidA gene and nptII gene) and cultured on selection medium containing $100 \mathrm{mg} \mathrm{l}^{-1}$ of kanamycin (Figure 3b). Moreover, the Catuaí suspension cultures showed a continuous growth and remained yellow during the selection period with $100 \mathrm{mg} \mathrm{l}^{-1}$ of kanamycin (Figure 3c). In contrast, other Catuaí suspension cultures turned brown and growth was inhibited after 4 weeks of culture on selection medium with $100 \mathrm{mg} \mathrm{l}^{-1}$ of hygromycin (pCAMBIA 1301 and pCAMBIA 1305.2) or $3 \mathrm{mg} \mathrm{l}^{-1}$ ammonium glufosinate (pCAMBIA 1301-BAR) (Figure 3d).

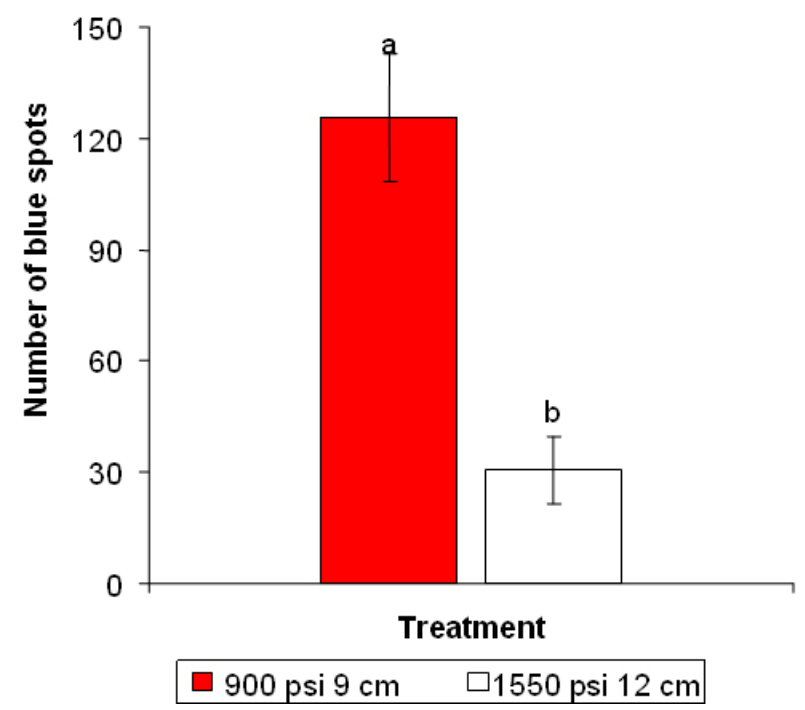

Figure 4. Effect of helium pressure and target distance on transient uidA expression in coffee suspension cultures (Coffea arabica L. cv. Catuaí). Errors bars correspond to SE. Data were recorded $48 \mathrm{hrs}$ after particle bombardment by GUS assay. Different letters indicate values are significantly different by Duncan test at $P>0.05$. 


\section{DISCUSSION}

A protocol for the induction and proliferation of Caturra and Catuaí embryogenic callus and for development of somatic embryos from Catuaí suspension cultures was established in the present study. Germination and development of Catuaí somatic embryos into plants using RITA $^{\circledR}$ was also successfully obtained. Furthermore, an optimized bombardment protocol for DNA delivery into $C$. arabica L. cv. Catuaí was developed.

The influence of culture medium composition on induction of Caturra and Catuaí callus was clearly observed (Table 1). The S1 and S2 media (Sondahl et al. 1991) induced a higher percentage of callus formation, compared to $\mathrm{C}+\mathrm{E}$ media (van Boxtel and Berthouly, 1996). The media sequence $C+E$, which was initially developed for embryogenic callus induction in C. canephora, was found to be less efficient in inducing ISE in C. arabica species (van Boxtel and Berthouly, 1996). Callus induction was higher when basal medium was supplemented with 2,4-D and kinetin. A similar result was obtained by García and Menéndez (1987) in Catimor leaves cultured on MS medium supplemented with $4.52 \mu \mathrm{M}$ 2,4-D and $18.56 \mu \mathrm{M}$ kinetin.

Proliferation of suspension cultures was achieved with both CP (van Boxtel and Berthouly, 1996) and Sli (QuirozFigueroa et al. 2002) culture media. Although, the fresh weight of suspension cultures did not differ between both culture media (Figure 2), the Sli culture media was chosen for suspension cultures proliferation on liquid culture media. The differences in the mineral salts and plant growth regulator concentration between CP (half strength MS + 4.6 $\mu \mathrm{M}$ kinetin) and Sli (MS + 9.2 $\mu \mathrm{M}$ kinetin) culture media influenced the choice. Van Boxtel and Berthouly (1996) demonstrated that under an intensive photosynthetic photon flux the growth of suspension cultures was inhibited and the risk of polyphenolic oxidation increased. For these reasons, dark incubation was chosen for the proliferation of Catuaí suspension cultures.

In this study, the higher fresh weight was seen using Erlenmeyer flasks instead of RITA ${ }^{\circledR}$ (Table 2). In a continuous immersion system, the Catuaí suspension cultures are constantly immersed in the liquid media and the uptake and utilization of mineral nutrients, plant growth regulators and water could be higher and therefore, responsible for the higher fresh weight of suspension cultures. Recently, Chakrabarty et al. (2007) reported that in a continuous immersion bioreactor, apple shoots appeared to utilize more nutrients and uptake more water from liquid medium than these growing on temporary immersion system. Moreover, Chakrabarty et al. (2007) showed that the higher fresh weight per apple shoot and the number of shoot per explant were obtained using a continuous immersion bioreactor than a temporary immersion bioreactor. In this study, in the RITA $^{\circledR}$ the medium covers the suspension cultures during a min every 8 hrs. However this low immersion frequency could limit the uptake of mineral nutrients and plant growth regulators necessary for the proliferation of the suspension cultures. In this sense, Albarrán et al. 2005) demonstrated that immersion cycles of 1 min every 4 hrs increased fresh weight and somatic embryos number compared to immersions cycles of 1 min every 12 hrs or 24 hrs. Besides, in an agitated liquid medium embryogenic calli disaggregate allowing the formation of suspension cultures.

On the other hand, in the present study, there were no significant differences in the dry weight using Erlenmeyer and RITA $^{\circledR}$, indicating that Catuaí suspension cultures proliferation could be carried out using both systems. In contrast, Berthouly et al. (1995) observed higher growth of embryogenic cultures from different C. arabica genotypes in a temporary immersion system than in Erlenmeyer flasks. Moreover, Chakrabarty et al. (2007) reported that individual apple shoots obtained from temporary immersion system had higher dry mass than those obtained from continuous immersion system. Although, coffee cell proliferation is traditionally carried out using Erlenmeyer flasks, using RITA $^{\circledR}$ to multiply embryogenic calli much larger containers can be used, transfer times can be reduced, permitted control of hyperhydricity and the labour, the number of containers and the space required can be reduced (Etienne and Berthouly, 2002; Chakrabarty et al. 2007).

Table 6. Effect of the culture system on the germination of somatic embryos and conversion into Coffea arabica L. cv. Catuaí plantlets after 12 weeks of culture on semisolid Yasuda medium.

\begin{tabular}{|c|c|c|c|}
\hline Culture system & $\begin{array}{c}\text { Germination of } \\
\text { embryos (\%) }\end{array}$ & $\begin{array}{c}\text { Conversion of } \\
\text { embryos into plants (\%) }\end{array}$ & $\begin{array}{c}\text { Fresh weight of plants } \\
\text { (mg) }\end{array}$ \\
\hline Semisolid media & $98 \pm 2 \mathrm{a}$ & $64.0 \pm 10.7 \mathrm{a}$ & $36.3 \pm 11.3 \mathrm{~b}$ \\
\hline RITA $^{\circledR}$ & $100 \mathrm{a}$ & $45.3 \pm 5.1 \mathrm{a}$ & $124.6 \pm 16.3 \mathrm{a}$ \\
\hline
\end{tabular}

Same letters within columns denote statistically equal means with the Duncan test at $P<0.05$. 
Differences observed in the regeneration efficiency of the suspension cultures could be related to differences in the concentration of plant growth regulators between both culture media (Table 4). The regeneration medium $\mathrm{R}$ (van Boxtel and Berthouly, 1996) contained 17.6 $\mu \mathrm{M}$ of BAP whereas the S3 medium (Quiroz-Figueroa et al. 2002) contained $2.32 \mu \mathrm{M}$ of kinetin and $0.27 \mu \mathrm{M}$ of napthaleneacetic acid (NAA). Somatic embryo development from embryogenic callus or suspension cultures has been accomplished previously in coffee mainly on semisolid culture media (Barry-Etienne et al. 2002b; Barrueto et al. 2004; Samson et al. 2006). Temporary immersion culture systems have improved the development of somatic embryos in Citrus deliciosa, Hevea brasiliensis, Musa spp and C. arabica F1 hybrid (Caturra x E531) (Escalant et al. 1994; Cabasson et al. 1997; Etienne et al. 1997; Barry-Etienne et al. 1999; Barry-Etienne et al. 2002a). Although, the results obtained in the present study did not show significant differences between semisolid or liquid media contained in RITA $^{\circledR}$ (Table 3 ), the time required for somatic embryo regeneration, germination and development of embryos into plantlets was reduced by two weeks using liquid culture media in RITA ${ }^{\circledR}$. Moreover, with regard to germination and conversion of somatic embryos into plantlets, in the present study the fresh weight of plantlets was higher using liquid than semisolid culture media (Table 6). It is well known that in semisolid media the growth rate is slow and the uptake of water, mineral nutrients and plant growth regulators is reduced by gelling agent compared to liquid culture media. Moreover, inhibitory and toxic exudates from explants do not diffuse quickly as in liquid culture media (Gupta and Timmis, 2005).

In culture systems with temporary tissue immersions, the immersion time is very important, since it determines nutrient and plant growth regulator uptake and can influence hyperhydricity (Etienne and Berthouly, 2002). Among the different immersion times used for formation of somatic embryos from suspension cultures, it was shown that the largest amounts of somatic embryos, the highest fresh weight of embryos and lowest fresh weight of callus were obtained using short immersions (Table 5). A similar result was obtained by Albarrán et al. (2005), who showed that short immersion periods ( 1 min every 12 hrs) strongly promoted the embryo production in coffee compared to long immersion duration (5 and 10 min every 12 hrs).

Optimization of parameters for particle bombardment is necessary for transient or stable gene expression in any plant tissue (Tee and Maziah, 2005). In a previous work, Rosillo et al. (2003) evaluated interactions among osmotic treatment, helium pressure and target distance for bombardment of C. arabica cv. Colombia line BK620. These authors concluded that 4 hrs of culture of the cells with $0.5 \mathrm{M}$ mannitol and sorbitol prior to particle bombardment, 900 psi with $9 \mathrm{~cm}$ or 1550 psi with $12 \mathrm{~cm}$ gave the highest transient GUS expression. To the best of our knowledge this is the first report of optimization of biolistic parameters for DNA delivery into C. arabica cv. Catuaí suspension cultures. The results obtained have shown that a lower helium pressure (900 psi) and shorter target distance $(9 \mathrm{~cm})$ may improve transient uidA expression compare to 1550 psi with $12 \mathrm{~cm}$ (Figure 4).

Simultaneously for the optimization of physical, biological and environmental parameters that affect the efficiency of the biolistic procedure, the choice of suitable selectable marker, its optimal concentration and the timing of selection are critical (Tadesse et al. 2003; Ribas et al. 2006). Selection agents must allow the proliferation of transformed cells and reduced tissue polyphenolic oxidation. Selection of coffee transgenic plants has been reported using hygromycin (Hatanaka et al. 1999; Kumar et al. 2006), kanamycin (Hatanaka et al. 1999; Canche-Moo et al. 2006), chlorsulfuron (Leroy et al. 2000) and ammonium glufosinate (Fernández- Da Silva and Menéndez- Yuffá, 2003; Ribas et al. 2005). Although transient uidA expression was observed on Catuaí suspension cultures bombarded with pCAMBIA 1301 ( $h p t$ and uidA) or pCAMBIA 1305.2 (uidA version GUSPlus ${ }^{\mathrm{TM}}$ and $h p t$ ) in this work the use of hygromycin and ammonium glufosinate led to oxidation of suspension cultures (Figure 4d). In this regard, van Boxtel (1997) reported that hygromycin caused inhibition of calli formation and severe necrosis on coffee leaves and suspension cultures. Moreover, these authors indicated that selection using 100 $\mathrm{mg} \mathrm{l}^{-1}$ kanamycin or $3 \mathrm{mg} \mathrm{l}^{-1}$ ammonium glufosinate inhibit growth of coffee suspension cultures without causing severe necrosis. However, in this study, the selection of transformed Catuaí suspension cultures with ammonium glufosinate and hygromicin was inhibited by the oxidation of the tissue. This result is probably due the damage caused by transformation of small size target tissue $(0.1$ to $0.3 \mathrm{~cm})$ and its sensibility to selection agent. Fernández- Da Silva and Menéndez-Yuffá (2003) indicated that released of phenolic compounds is a problem that affects genetic transformation in coffee.

Size of tissue is an important factor that needs to be considered for multiplication and regeneration of bombarded explants. Since particle bombardment involves the penetration of heavy metal particles into intact cells or tissues, microparticles hits may provoke various levels of tissue wounding and damage that can hinder plant regeneration (Tadesse et al. 2003). In this sense, when fine Catuaí callus aggregates $(0.1-0.3 \mathrm{~cm})$ were bombarded with pCAMBIA 1301 or pCAMBIA 1301-BAR no stable expression of uidA, hpt or bar genes was obtained. In contrast, stable expression of uidA gene was obtained when small Catuaí callus aggregates $(0.5-1 \mathrm{~cm})$ were bombarded with PCAMBIA 2301.

Mass propagation and plantlet regeneration via ISE required seven to eight months in C. canephora and Arabusta and nine to ten months in C. arabica (van Boxtel and Berthouly, 1996). In this study, plantlet regeneration from cultured leaves of $C$. arabica cv. Catuaí via ISE was 
accomplished in five to six months. To the best of our knowledge, this is the first report in which somatic embryo development from suspension cultures of C. arabica cv. Catuaí, germination and conversion of these embryos into plantlets, have been accomplished using temporary immersion culture in a RITA ${ }^{\circledR}$ bioreactor. Furthermore, the optimized genetic transformation protocol developed in the present study could be used for incorporation and stable expression of cry genes from Bacillus thuringiensis in order to confer resistance to Hypothenemus hampei, a very important insect plague in this culture.

\section{ACKNOWLEDGMENTS}

The authors are grateful to V.M. Jiménez (CIGRAS, University of Costa Rica) for the heplful disscusion and critical review of the manuscript.

\section{REFERENCES}

ALBARRÁN, J.G.; BERTRAND, B.; LARTAUD, M. and ETIENNE, E. Cycle characteristics in a temporary immersion bioreactor affect regeneration, morphology, water and mineral status of coffee (Coffea arabica L.) somatic embryos. Plant Cell, Tissue and Organ Culture, April 2005, vol. 81, no. 1, p. 27-36.

ALPIZAR, E.; DECHAMP, E.; ESPEOUT, S.; ROYER, M.; LECOULS, A.C.; NICOLE, M.; BERTRAND, B.; LASHERMES, P. and ETIENNE, H. Efficient production of Agrobacterium rhizogenes-transformed roots and composite plants for studying gene expression in coffee roots. Plant Cell Reports, September 2006, vol. 25, no. 9, p. 959-967.

BARRUETO CID, L. Pedro; RAMOS CRUZ, Andréa and RODRIGUEZ CASTRO, Luis. Somatic embryogenesis from three coffee cultivars: Rubi, Catuaí Vermelho 81 and IAPAR 59. HortScience, February 2004, vol. 39, no. 1, p. 130-131.

BARRY-ETIENNE, D.; BERTRAND, B.; VASQUEZ, N. and ETIENNE, H. Direct sowing of Coffea arabica somatic embryos mass-produced in a bioreactor and regeneration of plants. Plant Cell Reports, December 1999, vol. 19, no. 2, p. 111-117.

BARRY-ETIENNE, D.; BERTRAND, B.; SCHLONVOIGT, A. and ETIENNE, $H$. The morphological variability within a population of coffee somatic embryos produced in a bioreactor affects the regeneration and the development of plants in nursery. Plant Cell, Tissue and Organ Culture, February 2002a, vol. 68, no. 2, p. 153-162.

BARRY-ETIENNE, D.; BERTRAND, B.; VASQUEZ, N. and ETIENNE, $\mathrm{H}$. Comparison of somatic embryogenesisderived coffee (Coffea arabica L.) plantlets regenerated in vitro or ex vitro: morphological, mineral and water characteristics. Annals of Botany, July 2002b, vol. 90, no. 1, p. 77-85.

BERTHOULY, M.; DUFOUR, M.; ALVARD, D.; CARASCO, C.; ALEMANNO, L. and TEISSON, C. Coffee micropropagation in a liquid medium using the temporary immersion technique. In: $16^{\text {th }}$ International Scientific Colloquium on Coffee, ASIC (1995, Kyoto, Japan). Abstracts, 1995, p. 514- 519. Available from Internet: http://www.asic-cafe.org/pdf/abstract/16_025.pdf.

CABASSON, C.; ALVARD, D.; DAMBIER, D.; OLLITRAULT, P. and TEISSON, C. Improvement of Citrus somatic embryo development by temporary immersion. Plant Cell, Tissue and Organ Culture, July 1997, vol. 50, no. 1, p. 33-37.

CANCHE-MOO, R.L.R.; KU-GONZALEZ, A.; BURGEFF, C.; LOYOLA-VARGAS, V.M.; RODRIGUEZ-ZAPATA, L.C. and CASTAÑO, E. Genetic transformation of Coffea canephora by vacuum infiltration. Plant Cell, Tissue and Organ Culture, March 2006, vol. 84, no. 3, p. 373-377.

CHAKRABARTY, D.; DEWIR, E.H.Y.; HAHN, E.E.J.; DATTA, E.S.K. and PAEK, E.K.Y. The dynamics of nutrient utilization and growth of apple root stock 'M9 EMLA' in temporary versus continuous immersion bioreactors. Plant Growth Regulation, January 2007, vol. 51, no. 1, p. 11-19.

ESCALANT, J.V.; TEISSON, C. and COTE, F. Amplified somatic embryogenesis from male flowers of triploid banana and plantain cultivar (Musa spp.). In vitro Cellular and Developmental Biology - Plant, 1994, vol. 30, no. 4, p. 181-186.

ETIENNE, H.; LARTAUD, M.; MICHAUX-FERRIERE, N.; CARRON, M.P.; BERTHOULY, M. and TEISSON, C. Improvement of somatic embryogenesis in Hevea brasiliensis (Müll. Arg.) using temporary immersion technique. In vitro Cellular and Developmental Biology Plant, April 1997, vol. 33, no. 2, p. 81-87.

ETIENNE, H. and BERTRAND, B. Trueness-to-type- and agronomic characteristics of Coffea arabica trees micropropagated by the embryogenic cell suspension technique. Tree Physiology, September 2001, vol. 21, no. 14, p. 1031-1038.

ETIENNE, H.; ANTHONY, F.; DUSSERT, S.; FERNANDEZ, D.; LASHERMES, P. and BERTRAND, B. Biotechnological applications for the improvement of coffee (Coffea arabica L.). In vitro Cellular and Developmental Biology - Plant, March 2002, vol. 38, no. 2, p. 129-138.

ETIENNE, $H$. and BERTHOULY, M. Temporary immersion systems in plant micropropagation. Plant Cell, 
Tissue and Organ Culture, June 2002, vol. 69, no. 3, p. 215231.

ETIENNE, H. and BERTRAND, B. Somaclonal variation in Coffea arabica: effects of genotype and embryogenic cell suspension age on frequency and phenotype of variants. Tree Physiology, April 2003, vol. 23, no. 6, p. 419-426.

FERNANDEZ-DA SILVA, Rafael and MENENDEZYUFFA, Andrea. Transient gene expression in secondary somatic embryos from coffee tissues electroporated with the gene gus and bar. Electronic Journal of Biotechnology [online]. 15 April 2003, vol. 6, no. 1. Available from Internet:

http://www.ejbiotechnology.info/content/vol6/issue1/full/6/. ISSN 0717-3458.

GARCIA, E. and MENENDEZ, A. Embriogénesis somática a partir de explantes foliares del cafeto 'Catimor'. Café, Cacao, Thé, January 1987, vol. 31, no. 1, p. 15-22.

GUPTA, Pramod K. and TIMMIS, Roger. Mass propagation of conifer tress in liquid cultures-progress towards commercialization. Plant Cell, Tissue and Organ Culture, June 2005, vol. 81, no. 3, p. 339-346.

HATANAKA, T.; CHOI, Y.E.; KUSANO, T. and SANO, H. Transgenic plant of coffee Coffea canephora from embryogenic callus via Agrobacterium tumefaciensmediated transformation. Plant Cell Reports, December 1999, vol. 19, no. 2, p. 106-110.

KUMAR, V.; SATYANARAYANA, K.V.; SARALA ITTY, S.; INDU, E.P.; GIRIDHAR, P.; CHANDRASHEKAR, A. and RAVISHANKAR, G.A. Stable transformation and direct regeneration in Coffea canephora P ex. Fr. by Agrobacterium rhizogenes mediated transformation without hairy-root phenotype. Plant Cell Reports, March 2006, vol. 25, no. 3, p. 214-222.

LEROY, T.; HENRY, A.-M.; ROYER, M.; ALTOSAAR, I.; FRUTOS, R.; DURIS, D. and PHILIPPE, R. Genetically modified coffee plants expressing the Bacillus thuringiensis cry1Ac gene for resistance to leaf miner. Plant Cell Reports, March 2000, vol. 19, no. 4, p. 382-389.

MOLINA, Diana; APONTE, María E.; CORTINA, Hernando and MORENO, Germán. The effect of genotype and explant age on somatic embryogenesis of coffee. Plant Cell, Tissue and Organ Culture, November 2002, vol. 71, no. 2, p. 117-123.

MOREL, G.M. Clonal propagation of orchids by meristems culture. Cymbidium Soc News, 1965, vol. 20, p. 3-11.

MURASHIGE, Toshio and SKOOG, Folke. A revised medium for rapid growth and bioassays with tobacco tissue culture. Physiologia Plantarum, July 1962, vol. 15, no. 3, p. 473-497.
NEUENSCHWANDER, Beat and BAUMANN, Thomas W. A novel type of somatic embryogenesis in Coffea arabica. Plant Cell Reports, January 1992, vol. 10, no. 12, p. 608-612.

OGITA, S.; UEFUJI, H.; CHOI, Y.; HATANAKA, T.; OGAWA, M.; YAMAGUCHI, Y.; KOIZUMI N. and SANO, H. Genetic modification of coffee plants. Journal of Plant Biotechnology, 2002, vol. 3, p. 91-94.

QUIROZ-FIGUEROA, F.R.; MENDEZ-ZEEL, M.; LARQUE-SAAVEDRA, A. and LOYOLA-VARGAS, V.M. Picomolar concentrations of salicylates induce cellular growth and enhance somatic embryogenesis in Coffea arabica tissue culture. Plant Cell Reports, December 2001, vol. 20, no. 8, p. 679-684.

QUIROZ-FIGUEROA, F.R.; FUENTES-CERDA, C.F.J.; ROJAS-HERRERA, R. and LOYOLA-VARGAS, V.M. Histological studies on the developmental stages and differentiation of two different somatic embryogenesis systems of Coffea arabica. Plant Cell Reports, June 2002, vol. 20, no. 12, p. 1141-1149.

RIBAS, A.F.; KOBAYASHI, A.K.; PEREIRA, L.F.P. and VIEIRA, L.G.E. Genetic transformation of Coffea canephora by particle bombardment. Biologia Plantarum, December 2005, vol. 49, no. 4, p. 493-497.

RIBAS, Alessandra Ferreira; PEREIRA, Luiz Filipe P. and VIEIRA, Luiz Gonzaga E. Genetic transformation of coffee. Brazilian Journal of Plant Physiology, JanuaryMarch 2006, vol. 18, no. 1, p. 83-94.

ROSILLO, G., Adriana; ACUÑA, José R.; GAITAN, Alvaro L. and PEÑA, Myriam de. Optimized DNA delivery into Coffea arabica suspension culture cells by particle bombardment. Plant Cell, Tissue and Organ Culture, July 2003, vol. 74, no. 1, p. 45-49.

RUSSELL, Julie A. The Biolistic ${ }^{\circledR}$ PDS-100/He device. Plant Cell, Tissue and Organ Culture, June 1993, vol. 33, no. 3, p. 221-226.

SAMSON, N.P.; CAMPA, C.; LE GAL, L.; NOIROT, M.; THOMAS, G.; LOKESWARI, T.S. and KOCHKO, A. de. Effect of primary culture medium composition on high frequency embryogenesis in different Coffea species. Plant Cell, Tissue and Organ Culture, July 2006, vol. 86, no. 1, p. 37-45.

SANTANA, N.; GONZALEZ, M.E.; VALCARCEL, M.; CANTO-FLICK, A.; HERNANDEZ, M.; FUENTESCERDA, C.F.J.; BARAHONA, F.; MIJANGOS-CORTES, J. and LOYOLA-VARGAS, V.M. Somatic embryogenesis: a valuable alternative for propagating selected robusta coffee (Coffea canephora) clones. In vitro Cellular and Developmental Biology - Plant, January 2004, vol. 40, no. 1, p. 95-101. 
SANTOS-BRIONES, César Y. de los and HERNANDEZSOTOMAYOR, Teresa. Coffee biotechnology. Brazilian Journal of Plant Physiology, January-March 2006, vol. 18, no. 1, p. 217-227.

SONDAHL, M.R.; NAKAMURA, T. and SHARP, W.R. Propagación in vitro del café. In: ROCA, W.M. and MROGINSKY, L. eds. Cultivo de tejidos en la agricultura: Fundamentos y aplicaciones. Colombia, CIAT, 1991, p. 622-642.

TADESSE, Yohannes; SAGI, László; SWENNEN, Rony and JACOBS, Michel. Optimisation of transformation conditions and production of transgenic sorghum (Sorghum bicolor) via microparticle bombardment. Plant Cell, Tissue Organ Culture, October 2003, vol. 75, no. 1, p. 1-18.

TEE, Chong Siang and MAZIAH, Mahmood. Optimization of biolistic bombardment parameters for Dendrobium Sonia 17 calluses using GFP and GUS as the reporter system. Plant Cell, Tissue Organ Culture, January 2005, vol. 80, no. 1, p. 77-89.

VAN BOXTEL, Jos H.; BERTHOULY, Marc; CARRASCO, Cathy; DUFOUR, Magali and ESKES, Albertus. Transient expression of $\beta$-glucoronidase following biolistic delivery of foreing DNA into coffee tissues. Plant Cell Reports, October 1995, vol. 14, no. 12, p. $748-752$.

VAN BOXTEL, Jos and BERTHOULY, Marc. High frequency somatic embryogenesis from coffee leaves: factors influencing embryogenesis, and subsequent proliferation and regeneration in liquid medium. Plant Cell, Tissue Organ Culture, January 1996, vol. 44, no. 1, p. 7-17.

VAN BOXTEL, V.J.; ESKES, A. and BERTHOULY, M. Glufosinate as an efficient inhibitor of callus proliferation in coffee tissue. In Vitro Cellular \& Developmental Biology - Plant, January - January 1997, vol. 33, no. 1, p. 6-12.

YASUDA, Takeshi; FUJII, Yoko and YAMAGUCHI, Tadashi. Embryogenic callus induction from Coffea arabica leaf explant by benziladenine. Plant and Cell Physiology, April 1985, vol. 26, no. 3, p. 595-597.

ZAMARRIPA, A.; DUCOS, J.P.; BOLLON, H.; DUFOUR, M. and PETIARD, V. Production dథembryons somatiques de caféier en milieu liquide: effets densité d' inoculation et renouvellement du milieu. Café, Cacao, Thé, 1991, vol. 35, no. 4, p. 233-243. 